\title{
Normal, post-normal and new normal: A theology of hope in John 20:1-29
}

\begin{tabular}{|c|c|}
\hline $\begin{array}{l}\text { Author: } \\
\text { Johnson Thon }\end{array}$ & laskutty ${ }^{1,2}$ \\
\hline $\begin{array}{l}\text { Affiliations: } \\
\text { }{ }^{\text {Department }} \\
\text { Testament, Th } \\
\text { Theological Cc } \\
\text { Bengaluru, Inc }\end{array}$ & $\begin{array}{l}\text { f New } \\
\text { e United } \\
\text { llege, } \\
\text { lia }\end{array}$ \\
\hline $\begin{array}{l}\text { 2Department } \\
\text { Testament an } \\
\text { Literature, Fac } \\
\text { Theology and } \\
\text { University of } \\
\text { Pretoria, Sout }\end{array}$ & $\begin{array}{l}\text { f New } \\
\text { Related } \\
\text { ulty of } \\
\text { Religion, } \\
\text { retoria, } \\
\text { Africa }\end{array}$ \\
\hline $\begin{array}{l}\text { Research Proj } \\
\text { Project Leade } \\
\text { Project Numb }\end{array}$ & $\begin{array}{l}\text { ect Registration } \\
\text { r: E. van Eck } \mathbb{1} \\
\text { er: } 2400030\end{array}$ \\
\hline $\begin{array}{l}\text { Description: } \\
\text { This research } \mathrm{I} \\
\text { the research } \mathrm{p} \\
\text { 'Hermeneutics } \\
\text { directed by Pr } \\
\text { van Eck, Depa } \\
\text { New Testamer } \\
\text { Related Litera } \\
\text { Theology and } \\
\text { University of P }\end{array}$ & $\begin{array}{l}\text { s part of } \\
\text { roject } \\
\text { and Exegesis', } \\
\text { of. Dr Ernest } \\
\text { rtment of } \\
\text { it Studies and } \\
\text { ture, Faculty of } \\
\text { Religion, } \\
\text { retoria. }\end{array}$ \\
\hline $\begin{array}{l}\text { Correspondin } \\
\text { Johnson Thom } \\
\text { jesusandjohns }\end{array}$ & $\begin{array}{l}\text { g author: } \\
\text { laskutty, } \\
\text { on@gmail.com }\end{array}$ \\
\hline $\begin{array}{l}\text { Dates: } \\
\text { Received: } 03 \\
\text { Accepted: } 11 \\
\text { Published: } 21\end{array}$ & $\begin{array}{l}\text { lov. } 2021 \\
\text { ec. } 2021 \\
\text { Jan. } 2022\end{array}$ \\
\hline $\begin{array}{l}\text { How to cite th } \\
\text { Thomaskutty, } \\
\text { 'Normal, post- } \\
\text { new normal: A } \\
\text { hope in John } 2 \\
\text { HTS Teologiese } \\
\text { Theological St } \\
78(4), \text { a7214. } \\
\text { org/10.4102/h }\end{array}$ & $\begin{array}{l}\text { is article } \\
. ., 2022 \text {, } \\
\text { normal and } \\
\text { theology of } \\
0: 1-29^{\prime}, \\
\text { Studies/ } \\
\text { udies } \\
\text { ttps://doi. } \\
\text { ts.v78i4.7214 }\end{array}$ \\
\hline 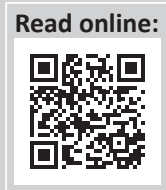 & $\begin{array}{l}\text { Scan this QR } \\
\text { code with your } \\
\text { smart phone or } \\
\text { mobile device } \\
\text { to read online. }\end{array}$ \\
\hline
\end{tabular}

Author:

\section{Affiliations:}

${ }^{1}$ Department of New

Bengaluru, India

${ }^{2}$ Department of New Testament and Related University of Pretoria, Research Project Registration Project Leader: E. van Eck (1) Description:

This research is part of directed by Prof. Dr Ernest van Eck, Department of New Testament Studies and Related Literature, Faculty of Theology and Religion, Johnson Thomaskutty,

Dates:

Accepted: 11 Dec. 2021 new normal: A theology of hope in John 20:1-29', HTS Teologiese Studies/ 78(4), a7214. https://doi. org/10.4102/hts.v78i4.7214

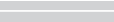

This article re-reads John 20:1-29 to foreground the normal, the post-normal and the new normal realities within the Johannine resurrection narrative. The narrator of John demonstrates the normal situational aspects by taking into consideration the setting, characterisation, thematic development, point of view and plot development of the story in closer relationship with the temporal and spatial mechanisms. The ordinary, local and existent realities are expressed to reveal the colourless human experiences in relation to the divine aspects within the narrative framework. The resurrection of Jesus introduces a post-normal situation within the Sitz im Leben Jesu and the Sitz im Leben Kirche. The post-normal situation was introduced by placing the story of Lazarus at a strategic place (Jn 11:1-45) and thereafter by unfolding the essentials such as speed, scope, scale and spontaneity. The unfolding of the divine within the existential human realities created a post-normal situation where the Johannine community had to undergo expulsion and persecution from the side of the dominant structures. The narrator gives the reader a hope about a new normal situation above and beyond the existent struggles of the Johannine community.

Contribution: This article presents a new perspective concerning the normal, the post-normal and the new normal realities and dynamism within John 20:1-29 and suggests a new way forward in interpreting the Fourth Gospel by taking into consideration the existential aspects of the COVID-19 and Omicron pandemic situations. As a contextual and theological interpretation of the Fourth Gospel, this article fits well within the scope of HTS Teologiese Studies/Theological Studies.

Keywords: normal; post-normal; new normal; John's Gospel; theology of hope.

\section{Introduction}

The present article attempts to foreground the dynamic integration of the normal, the postnormal and the new normal aspects within the Johannine resurrection narrative. While the normal can be characterised by the existent realities based on the temporal and spatial mechanisms in human situations, ${ }^{1}$ the post-normal can be characterised by the $4 \mathrm{~S}^{\prime} \mathrm{s}$ such as the speed, scope, scale and spontaneity of events because of the current developments in human life and by the 3Cs such as complexities, chaos and contradictions because of the COVID-19 and Omicron pandemic situations. Post-normal times (PNT) is a concept developed by Ziauddin Sardar with influences from post-normal science (PNS; Ravetz 1993:735-755; Ravetz \& Funtowicz 1999:641-646). ${ }^{2}$ The expression 'post-normal' was first used by J. R. Ravetz, a celebrated British philosopher of science and S.O. Funtowicz an Argentinean mathematician (Sardar 2010:435-444). ${ }^{3}$ The new normal is characterised by a new way forward in the future. Sardar (2010) stated:

We will have to imagine ourselves out of postnormal times and into a new age of normalcy - with an ethical compass and a broad spectrum of imaginations from the rich diversity of human cultures. (p. 435)

Sardar suggested a distinction among normal period, PNT and new age of normalcy (Kapoor 2011:216-220). ${ }^{4}$ He was hopeful about a new normalcy as he stated, 'The intellectuals, opinion1.A normal situation is a familiar or typical situation that has become a standard, usual or expected.

2.'Whenever there is a policy issue involving science', wrote Ravetz and Funtowics, 'we discover that facts are uncertain, complexity is the norm, values are in dispute, stakes are high, decisions are urgent and there is a real danger of man-made risks running out of control'.

3.Sardar explained, 'Much of what Ravetz and Funtowicz said about science in the 1990s are now equally true about other disciplinesindeed, society as a whole. Everything from economics to international relations, markets to products in local shops, politics to dissent has become post-normal'. Sardar described the present as 'post-normal times', 'in an in-between period where old orthodoxies are dying, new ones have yet to be born and very few things seem to make sense'.

4.Rakesh Kapoor critiqued the theory of Sardar in the following words: 'Ziauddin Sardar's characterisation of "post-normal times" elegantly captures the mood of despair, uncertainty and insecurity in the West because of the multiple shocks of terrorism, economic

Copyright: (C) 2022. The Authors. Licensee: AOSIS. This work is licensed under the Creative Commons Attribution License. 
makers and leaders of the world have to exercise their ethical responsibility and creative imagination to enable this new normalcy to emerge' (Sardar 2010:435-444). This framework is very important as we interpret the Scripture in today's context.

The PNT introduces novelty in our rapidly changing world, but at the same time a sense of ignorance and uncertainty prevails about the future. We are placed in a transitional or a liminal position. We can neither return to any known past nor can hope about a desirable future (Sardar 2010:1). As placed in the PNT context, we are expected to implement new models of biblical interpretation that take into account a rapidly changing period in human history. In this article, John 20:1-29 is chosen as a sample text to understand the normal, the post-normal and the new normal interaction within the textual horizon. The methodology of the article is framed, first, by making use of polyvalent literary and narrative aspects of the text, ${ }^{5}$ second, by adopting the PNT theories developed by Sardar and Sweeney and third, by deriving the narrative dynamics of the passage with normal, post-normal and new normal overtones (Sardar 2010:435-444; Sardar \& Sweeney 2016:1-13). The aim of the article is threefold: first, framing a theory of hermeneutics to meet the new demands introduced by the COVID-19 and Omicron pandemic contexts; second, understanding John 20:1-29 both within the larger framework of the Fourth Gospel and in relation to the contemporary realities; and third, developing a new way forward in biblical interpretation in the 'in-between' period of ours.

\section{Normal in the narrative}

The word 'normal' can mean 'usual,' 'typical' or 'expected state or condition.' It conforms to an existing standard within the time and space realities of human livelihood. Normal can be the ordinary things and events that shape the human thought-world. ${ }^{6}$ The events in the resurrection narrative in John 20:1-29 provide several clues regarding the ordinariness of human existence in the temporal and spatial mechanisms of the world (Estes 2008:31-70). ${ }^{7}$ The setting of the resurrection story reveals the ordinary and normal realities of human life as a woman is going to a tomb early on the first day of the week. The woman's love for her hero is explicit at the outset of the narrative framework (v. 1; Beasley-Murray 1999:367). Mary Magdalene, as a surprised and perplexed character, is running to Simon Peter and the other disciple (v. 2a). She expresses her emotions with ordinary implications: 'They have taken the Lord out of the tomb, and we don't know where they have put him' (v. 2b; Köstenberger 2004:561-562).

recession and climate change. However, the prevailing mood in India, most of Asia and developing countries in general is confidence and optimism for the future'.

5.David B. Gowler called this method a heteroglossia, a term used by Michael Bhaktin to mean 'the dynamic interaction of a number of voices, ideologies and positions, but none of them in pre-eminent, none rules or controls the others'. See Gowle (2000:443); also see Thomaskutty (2015:19-26); Lawrence (2018:428-430); Anderson (2008:93-120).

6.See https://encyclopedia2.thefreedictionary.com/normal+time, accessed on 30 October 2021

7.As per the Aristotelian logic, the 10 categories of human predicament include 'substance or being', 'quantity', 'quality', 'relation', 'place', 'time', 'posture', 'having or possession', 'action' and 'passion'.
The excitement of Peter and the other disciple forced them to start for the tomb (v. 3). Although the two disciples were running, one outran the other and reached the tomb first (v. 4; Beasley-Murray 1999:367-369). The excitement of the disciples is obvious from these ordinary and normal reactions and emotions they express. The narrator of the story creates the story world wrapped up in human sentiments, reactions, movements and other sensory aesthetic aspects (Ford 2021:394-415). ${ }^{8}$

When the other disciple bends over and looks into the tomb, it is obvious to see his eagerness about the events he had heard from Mary (v. 5a). Afterwards, Simon Peter, who was behind him, also arrives and visits the tomb (v. 6a; Köstenberger 2004:561-562). The speed of the other disciple in comparison to that of Peter is made obvious to the reader. At the first level, the other disciple bends over and looks into the tomb (v. 5a). Later on, the narrator reports that he also went inside the tomb (v. 8a; Moloney 1998:520,523). The things around him are narrated with a lot of ordinary overtones: in v. 5, he bent over, looked and saw vaguely and in v. $8 \mathrm{~b}$, he went inside, saw clearly and believed (Köstenberger 2004:561-562). After witnessing the empty tomb, the disciples went back to their homes (v. 10a; Moloney 1998:520-521). The return of the disciples to their homes demonstrates their unknowing and misunderstanding posture within the narrative framework. The human normalcy of the disciples is explicit in the narrative annals as they are not in a position to expect a dead one returning to life again (Ford 2021:394-415).

The human normalcy of the situations is further delineated as Mary expresses her human emotion of weeping and action of looking into the tomb (v. 11; Malina \& Rohrbaugh 1998:280). As it is a typical bereavement narrative created out of the contextual realities, ordinariness is used as one of the significant narrative asides within the passage. Mary's response to the angels delineates the following aspects: first, her perplexity about the stealing of the body of Jesus ${ }^{9}$ and second, her unknowing nature because of the accidental happenings around the tomb (v. 13b; Malina \& Rohrbaugh 1998:280). The woman's unknowing nature (v. 14) and her supposition that Jesus' body was taken away confirm her human settlements (v. 15b; Malina \& Rohrbaugh 1998:280-281). The disciples' fear of the Jews and their gathering inside a locked house reveal some of the normal human tendencies and happenings during critical situations (v. 19, 26a). Thomas' response to the other disciples amply demonstrates a realistic human perception (v. 25b; Malina \& Rohrbaugh 1998:280-281). Thus, ordinariness is at the root of the resurrection narrative.

The resurrection narrative in John is wrapped up in human ordinariness at several junctures: first, the characters within the story demonstrate themselves as flesh and blood characters

8.The ordinary situation of the narrative can be derived out of the ordinary human settings, characterisation and narrative point of view of the text.

9.This aspect is highlighted in Matthew 28:13. 
with human emotions and predicaments; second, the setting of the story is normal as the time and space aspects are clearly presented in and around the tomb of Jesus; third, the unknowing and misunderstanding situations in human life are clearly portrayed with a lot of naturalistic overtones; fourth, the missing body of Jesus is at focus as Mary witnesses the empty tomb (v. 1), she longs for the body of Jesus (vv. 2, $13 \mathrm{~b}, 15 \mathrm{~b})$ and she expresses her emotions and she moves in and around the tomb (Stibbe 1993:198-206); fifth, the point of view of the story is presented with a particular focus on the normal human reactions; sixth, the narrative develops as a post-normal event like the resurrection wrapped up within a canvas of ordinary human experiences; seventh, the plot of the story develops through three ordinary human situations: early on the first day of the week (vv. 1-18), on the evening of that first day of the week (vv. 19-25) and a week later (vv. 26-29; Stibbe 1993:203) and eighth, the props like the tomb (vv. 1, 2, 3, $4,6,8,11$ ), the stone (v. 1), the entrance (v. 1), strips of linen (vv. $5,6,7)$, burial cloth (v. 7), homes (v. 10), locked doors (v. 19, 26) and others give the reader an impression about the proximity to the events (Stibbe 1993:206).

\section{Post-normal in the narrative}

The narrator introduces a post-normal situation within the story through unfolding supernatural events in the human context and their universal impact. A normal and postnormal interaction is in view as the locally oriented normal human situations are chosen to present the universally oriented post-normal events. The post-normal situation is at view as the heavenly realities are introduced within the earthly setting. The $4 \mathrm{~S}^{\prime} \mathrm{s}$, speed, scope, scale and simultaneity, set the stage for PNT. In today's context, the movements are faster, from a period of acceleration to acceleration of acceleration. ${ }^{10}$ The globe is a village; hence, the scope is universal. A virus affects from a smaller village to the globe as a pandemic. This shows how the notion of scale is shrinking. Simultaneity is on an increase; when something happens, that affects the other happenings. ${ }^{11}$ The PNT's 4S dynamism can be understood well within the episodic framework of John's Gospel.

The $4 S^{\prime}$ s of the PNT functions in a dynamic and persuasive manner within John's narrative world. The narrator locates the story of Lazarus as a trigger narrative within the overall framework of the Gospel. The essentials such as speed, scope, scale and simultaneity are rhetorically presented as the story moves from the ordinary human realities in the first half to the PNT in the second half of the Gospel. ${ }^{12}$ Lazarus' death and raising and the consequent death of Jesus on the cross introduce several post-normal tendencies in the universal scenario (Vistar 2019:17-18). The narrator actualises all those aspects through the means of several ironical situations introduced within the text such as the trial of an innocent

10." $4 S^{\prime}$ ', " Postnormal Times, https://postnormaltim.es/essentials/4-ss, accessed on 04 September 2021.

11.“4S'S," Postnormal Times, https://postnormaltim.es/essentials/4-ss, accessed on 04 September 2021.

12.See https://postnormaltim.es/essentials, accessed on 24 September 2021. person, the passion of the saviour of the world, death on the cross as glorification and Jesus' resurrection even when the tomb was sealed (Duke 1985; Vistar 2019:17-18). These ironical situations in the Sitz im Leben Jesu are further reflected in the Sitz im Leben Kirche as the Johannine community was experiencing a PNT experience. The death of Jesus on the cross brought a lot of issues in the Johannine community context, such as identity crisis, expulsion from the synagogue, persecution, minority status and marginality. The narrator keeps the story of Lazarus at a strategic position to trigger the events thereafter with speed, scope, scale and simultaneity. ${ }^{13}$ Thus, the narrator invites the reader from the so-called normal situations in the first half to the post-normal situation in the second half of the Gospel (see Murray-Miller 2010:163-175).

Although the Lazarus' story sets a stage for the post-normal within John's Gospel, the event of Jesus' resurrection makes it more convincing. In John 20:1-29, the narrator unfolds some of the unusual happenings with focus in order to attune the reader's acumen towards the gnomic and universalistic aspects (Thomaskutty 2018:54-57). The removal of the stone from the tomb demonstrates that a post-normal situation was introduced within the story (v. 1). The absence of the body of Jesus in the tomb created a lot of movements around the tomb (vv. 2-10; Vistar 2019:17-18). The events before the resurrection in the local Israelite context are directed towards the post-resurrection events with universal connotations. The props such as the linen wrappings in the tomb even when the body is missing create wonder among the spectators (v. 5; Beasley-Murray 1999:371-372). Peter saw linen wrappings lying there and the cloth that had been on Jesus' head not lying with the linen wrappings but rolled up in a place by itself (vv. 6-7; Brant 2004:199; Cole 2015). These props are symbolic to invite the readers towards the post-normal situations introduced by the event of resurrection (Maniparampil 2004:353-355). The indication that the other disciple also saw and believed' widens the scope of the event from an individual level to the community of believers (v. 8; BeasleyMurray 1999:373).

The post-normal situation is filled with a lot of perplexities and misunderstandings among the spectators (vv. 9, 14-18; Beasley-Murray 1999:373, 374-378). The angelic appearance in verses 12-13 introduces the divine intervention in the human realities (Brant 2004:53, 54, 81). Mary's declaration in verse 18 (i.e. 'I have seen the Lord') is post-normal as she started to realise and recognise the new reality irrespective of the unknowing and misunderstanding situations (Moloney 1998:529). The Christophany in verses 19-23 and the assurance about the outpouring of the Holy Spirit introduce a post-normal situation (Maniparampil 2004:357-358). Further, the Christophany of John 20:24-29 revealed the postnormal situation with focus (Köstenberger 2004:572-573; Thomaskutty 2018:54-68).

13."4S'S," Post-normal Times, https://postnormaltim.es/essentials/4-ss, accessed on 04 September 2021. 
After the Lazarus event, the 3Cs are in an accelerating mode and hence things are surmounted in uncertainties and ignorance (Sardar 2010:6). When the 3Cs are aligned within the purview of the $4 \mathrm{Ss}$, the situation becomes unpredictable and challenging for human existence. The event of the death and raising of Lazarus and the resultant popularity of Jesus catapult to a complex, chaotic and contradictory situation where irregularities prevail and non-normal control everything (Moloney 2005:214-240). Lincoln (2000) stated:

$[L]$ ife for Lazarus means death for Jesus; in terms of our motif, the anticipation of the verdict of life for those who believe is what brings about the negative denouement of the verdict of death on Jesus. (p. 151)

The irregularities and non-normal are obvious as the religious, political and judicial systems function haphazardly both within the Sitz im Leben Jesu and within the Sitz im Leben Kirche (Martyn 1979). The death and resurrection of Jesus can be well connected to the death and raising of Lazarus. After the raising of Lazarus the 4Ss and the 3Cs are accelerating in a fast-pace mode aiming towards the death and the resurrection of Jesus (Moloney 2005:214-240). The Johannine narrator foregrounds the post-normal at its best through the resurrection of Jesus (Vistar 2019:17-18). This new situation within the Johannine narrative world can be better understood as a Sitz im Leben post-normal (see Ford 2021:394-415).

\section{New normal in the narrative}

As the narrator takes the attention of the reader towards a new normal situation in the Johannine community context, a contemporary reader of John can be hopeful about the future which lies ahead of her or him. A new hermeneutics that takes into account the post-normal life situations, the pluralistic, polylogic and complex contextual experiences, the paradigmatic Johannine situation, and a theology of hope derived out of the Sitz im Leben Jesu and Sitz im Leben Kirche realities can offer a transformative and liberative message to the people in the contemporary post-normal context. The resurrection narrative in John provides such a hope about the future (Thomaskutty 2021:1-17).

As the heavenly ushers in the earthly setting through the event of resurrection, the community situation demonstrates its post-normal experience. But, the heavenly directs the attention of the reader beyond the post-normal situation in life, that is, an ideal world is at view. The passage provides certain norms regarding the ideal and new normal realities. The power that worked behind Jesus' resurrection was beyond human comprehension. The Scripture points out that Jesus must rise from the dead (v. 9; Ridderbos 1987:634-635). The power of resurrection exhibited was beyond the postnormal realities. Although the resurrection ushered a new age in human history, it was rooted in the heavens. The earthly attunement to the heavenly realities is introduced through the appearance of the angels (v. 12; Ridderbos 1987:635-637). The responses of the angels (v. 13a) and Jesus (v. 15) are invitations to Mary to come to a world without tears (Ridderbos 1987:635-637). The Johannine community was in constant struggle as it was undergoing expulsion from the Synagogue and persecution because of their trust in Jesus. This post-normal situation was ushering a new way forward and a hopeful future in front of the community.

The new normal situation introduced to Mary comes to its fruition in verse 17: first, Jesus warns her to release him to go beyond the existential post-normal situation; second, the woman is instructed to proclaim about the ascension of Jesus (to a world beyond the post-normal situation) to the disciples and third, a clue is given that Jesus is 'ascending to my [his] Father and your [Mary's] Father, to my [his] God and your [Mary's] God' (Ridderbos 1987:637-640). She receives an open invitation and an attention to a world without weeping. Mary as an apostle to the apostles was instructed to pronounce the good news of a new world without fear, suffering and weeping (v. 18; Ridderbos 1987:640). The resurrected Jesus entrusted Mary to pronounce about a world beyond the existential post-normal world. The hope of a new world is at the core of the proclamation entrusted upon Mary.

The death and the subsequent resurrection of Jesus created a post-normal situation among the disciples of Jesus. The peace that Jesus offers to the disciples in vv. $19 \mathrm{~b}$ and $26 \mathrm{~b}$ can be an indication about a new normal situation in the future (Brant 2011:271, 272). The mission of the disciples is specified in the following way: 'As the Father has sent me, so I send you' (v. 21; Brant 2011:272). The events of breathing on them, coming of the Holy Spirit and the aspect of forgiveness are ways forward for the community of God (vv. 22-23; Brant 2011:272). The seeing aspect in verses 18 and 25 introduces a new reality (Brant 2011:271, 272). Believing is a new way forward for the Johannine community during a post-normal situation (v. 27) in order to hope for a new normal (Brant 2011:272, 273).

The passage provides the following clues regarding a new normal in the future. While the existent realities of the normal time were challenged by the resurrection of Jesus, an 'in-between' post-normal situation was created and such a context was with a lot of complexities, chaos and contradictions in the life realities of the Johannine community. Jesus' promise in the Farewell Discourse concerning a place beyond the existent aspects gives hope for the people who are under trial. The following things are emphasised in 14:1-4: first, the disciples are encouraged to live peacefully in troublesome situations (14:1a; Witherington 1995:248); second, they are persuaded to 'trust in God; trust also in me [Jesus]' (14:1b; Witherington 1995:248-249); third, the Father's house has many rooms (14:2a); fourth, Jesus goes to the Father's house to prepare a place for the disciples $(14: 2 b, 3 a)$; fifth, Jesus shall come back and take the disciples along (14:3b; Witherington 1995:248-249); sixth, the disciples are going to be with Jesus in the future (14:3b) and seventh, the disciples shall know the place where Jesus is going (14:4; Witherington 1995:248-249). The resurrection was the final stage of Jesus' being in the world and the disciples are given a hope concerning a new normal as they follow a crucified master and undergo difficult situations. The hope about the future 
enabled the community to suffer the trials and persecution during the post-normal situations in their lives.

\section{A theology of hope}

A theology of hope is at the centre of John's resurrection stories. The two resurrection stories described in John (11:1-45 and 20:1-29) can be understood from the perspective of a new normal within the Johannine community. There are connecting links between the Lazarus' story in John 11 and the story of Jesus in John 19-20. The following five things are outlined here for clarity. First, the narrator uses derivatives of thanatos (i.e. death) in both the cases of Lazarus $(11: 4,13,14$, $16,21,25,26,32,37)$ and of Jesus $(11: 50 ; 19: 7)$. While the derivatives of thnēskō $(11: 44 ; 19: 33)$ are used in both the cases, the expression nekpēn (a derivative of nekros, 20:9) is used only in relation to Jesus. While the act of death is at focus in Lazarus' case, the process of death is emphasised in relation to Jesus (Moloney 1998:515-540; Smith 1999:216-227). Second, while the raising of Lazarus is expressed with exupnisō (to awaken, 11:11) and derivatives of anastasis (11:23, 24 [x2], 25), Jesus' resurrection is expressed with eggeiren (raised, 12:1) and egertheis (having been raised, 21:14). While Lazarus' raising is presented in a temporary sense, Jesus' resurrection is presented with an eternal perspective (Moloney 1998:515-540; Smith 1999:216-227). Third, in John, the theme of doxa is mostly used in relation to the glory of Jesus (or God). The usage of glory in the micro-level (11:4 and 40) aligns well within the overall coverage of the term glory within the framework of the Fourth Gospel (5:41-42; 7:18; $8: 50 ; 12: 43 ; 17: 5,24)$. Death is mostly demonstrated as glory, in the public ministry of Jesus $(11: 4,40)$, during the death of Jesus (ch. 19-20) and even after the resurrection (21:19; Moloney 1998:515-540; Smith 1999:216-227). Fourth, there are similarities between the tomb stories of Lazarus and Jesus (11:1-45; ch. 19-20) as both the cases have strips of cloth (11:44; 20:5-6) and head cloths (11:44; 20:7). While strips of cloth is generally mentioned in the Lazarus event (keiriais, 11:44), it is specifically mentioned as linen clothes (othoniois, 19:40; 20:5-6) in Jesus' story (Carson 1991:634-639). But, in both the cases the head cloth is mentioned as soudarion (11:44; 20:7). While Lazarus comes out bound (11:44), Jesus' napkin clothes are lying there and linen clothes are nicely folded together (20:7). While the stone from Lazarus' tomb was taken away (11:41), the stone had already been removed from the grave of Jesus (20:1). Fifth, while the weeping of the people indicated with the derivatives of klaio $(11: 33 ; 20: 11,13$, 15), Jesus' is addressed as edakrusen (shedding tears, 11:35; Moloney 1998:515-540; Smith 1999:216-227).

The given details in the two resurrection narratives teach us the following lessons. First, the believing community shall not merely confront an act of death but a process of death as Jesus had exemplified. The expulsion from the synagogue, the suffering and the persecution are part and parcel of Christian living in the world. The Johannine community was instructed that they shall undergo difficult situations during the postnormal situations. Second, although the post-normal situations are real, the people of God are promised a future resurrection to be elevated to the heavenly realities. Third, as the glory of God/Jesus was revealed through the death and resurrection of Jesus, the community of God, through the process of suffering and death, can manifest the glory of God/Jesus during the PNT. Fourth, the props like the linen clothes and the napkin (head) clothes in Jesus' tomb reveal the fact that those who suffer, undergo persecution and embrace death shall be resurrected in the future glorious abode of God. Fifth, while the world weeps without a hope, the people of God shed tears with a hope about the eternal future. While the death and the raising of Lazarus point to the death and the resurrection of Jesus, the death and the resurrection of Jesus point to the new normal situation in the future glorious Kingdom of God (Murray-Miller 2010:163-175).

A theology of hope is at the centre of Johannine resurrection narratives. The raising of Lazarus in 11:1-45 delineate the following symbolical aspects: first, the Johannine community was in death-like situations as they were expelled from the synagogue and many of the community members were under persecution; second, the Jews are critical towards the emerging community as they were antagonistic to both Lazarus and Jesus (11:45-53; 12:1-11); third, while the trial of the man born blind (9:1-41) functions as an analepsis to Jesus' trial and passion in chapters 18-19, the death and raising of Lazarus (11:1-45) function as an analepsis to Jesus' death and resurrection in chapters 19-20; fourth, the speed, scope, scale and spontaneity created in the second half of the Gospel through the introduction of Lazarus' story attunes well with the death and the resurrection of Jesus; fifth, the raising of Lazarus was symbolically presented in order to demonstrate Jesus' love for the sheep as a good shepherd (10:1-11) and giver of life and resurrection (11:25); sixth, Lazarus' character as a 'beloved disciple' (11:3) and as a representative of the community reveals the shepherd and sheep relationship; seventh, Jesus' shedding of tears by the tomb of Lazarus and the subsequent action of raising the dead one demonstrate his concern for the suffering humanity; eighth, the partial glory that Jesus reveals by raising Lazarus $(11: 4,40)$ enables the family of Martha and Mary to come to a joyous situation; ninth, while the raising of Lazarus prefigures the event of Jesus' resurrection with post-normal implications in the Johannine community context, the resurrection of Jesus prefigures the resurrection of the dead ones in Christ with new normal implications in the future glorious age; and tenth, the post-normal realities of the Johannine community as they confront death, bereavement, opposition, persecution and expulsion are symbolically and figuratively presented through the representative story of Lazarus. The story enables the community to be hopeful even in the midst of death-like situations and expulsions by placing Jesus' identity at the centre of their living together.

While the story of Lazarus equips the community to build hope even in the midst of post-normal situations in life, the resurrection of Jesus builds the hope of the community further about the futuristic new normal situations in life. The 
passion and resurrection of Jesus symbolically conveys several messages: first, the members of the Johannine community shall be protected during the PNT and a new normal awaits for them in the future; second, the members of the Johannine community, although they undergo passion, persecution and death, shall be resurrected in the future to enjoy the blessings and favours of God; third, while the members of the Johannine community are in misunderstanding and unknowing situations (20:15), Jesus reveals to them the new normal that arrives in the future; fourth, Jesus' return to the Father indicated in v. 17 further strengthens his promises in the Farewell Discourses (14:1-4); fifth, the mysterious expression of Jesus to Mary (i.e. 'I am returning to my Father and your Father, to my God and your God', 20:17b) confirms the Christian community that as Jesus was ascended to the Father the Christian community also shall be ascended to the Father; sixth, the resurrected Jesus' offer of peace to the fearful disciples assures that a new normal situation is just ushered through the resurrection of Jesus (20:19b, 21, 26b); seventh, the ascending and descending motif of the Johannine framework is significant to interpret the missional statement of Jesus in v. $21^{14}$; eighth, the Holy Spirit guides the believers during the post-normal situations to accomplish the mission of God irrespective of all the difficulties of the world (20:22-23); ninth, believing in the resurrected Jesus is the prerequisite for the community to be qualified for the new normal situation (20:27-29); and tenth, a resurrection hope and a hope about the new normal are at the centre of John's narrative master piece (Kim 2018:129-160). Thus, there is a transfer of order from the post-normal suffering situations to a new normal introduced by heavenly initiatives.

The Indian and the African communities should consider the death and resurrection of Jesus in new lights. The significance of the resurrection of Jesus in the Indian and the African contexts is multifaceted. When we discuss the theme of resurrection in the multireligious, multicultural and pluralistic contexts of India and Africa, we need to reinterpret the significance of Christ's resurrection for our diverse communities (Mulder 2021). The salvific significance of Christ's work on the cross and his resurrection should first and foremost be introduced, as the good news of salvation for the various ethnic communities (Gorman 2021). As a second order to this, when we witness Christ for instance to the Dalits (untouchables or scheduled caste people), Tribals, Adivasis (indigenous people or scheduled tribes), Apartheid impaired and racially marginalised (the poor and dehumanised, also called the dust of the dust), we can use Christ's resurrection as a model for liberation out of the clutches of oppression (Gorman 2021). As Christ was humiliated on the cross and was raised by the Father from the grave, so also, Christian mission should focus on the upliftment of the oppressed out of the bondages of poverty, casteism, colour-bias, sin and injustice. Resurrection is therefore a unique missional paradigm, comprising the

14.Jesus descended from the Father and now he returns to the heavens after finishing the mission of God; the disciples are descending as Jesus sends them to the world and when they accomplish the mission of God in the world, they shall be ascended into the Father's world. historical reality of Christ's resurrection, its salvific significance and its social implications in the contemporary context (Mulder 2021). During the COVID-19 and Omicron pandemic contexts, the message of resurrection enables the community of believers to cope with the crises situation and hope about the future new normal situation.

\section{Concluding remarks}

This article attempted to interpret John's resurrection narrative by using a polyvalent analysis. I attempted to foreground the normal, post-normal and new normal aspects of the Johannine community in order to present an interpretative paradigm in the contemporary global scenario. The text reveals several aspects of human normalcy in the settings, characterisation, thematic development, point of view and plot structure. The normal situations were drastically changed in speed, scope, scale and spontaneity as the divine appeared in the ordinary human situations through the person and work of Jesus. The conflict between the divine and the human and the resultant antagonism of the world against the divine led to the passion, crucifixion, death and the resurrection of Jesus. The unfolding of the post-normal in the Sitz im Leben Jesu and the Sitz im Leben Kirche created a division between the divine and the human in the universal scenario and the power-structures of this world started to dominate the Johannine sectarians. The division unfolded between the world from above and the world from below resulted into a post-normal situation. The complex, chaotic and contradictory situation emerged in the Johannine community led them to experience an 'in-between' liminal situation. But, the hour or lifting up or glorification of the Son of Man and the resultant resurrection opened a new way forward for the suffering community. The hope that the resurrection of Jesus brought in the Johannine community context enabled them to think about a new normal situation ahead.

The cross of Jesus demonstrates the power of God. The community is encouraged to be hopeful about the future glorious age with the presence of God the Father, Jesus the begotten one of God and the heavenly beings. There is hope for the suffering, dehumanised, dying and ostracised as they focus on the cross of Jesus. The Dalits, the tribals, the adivasis, the apartheid impaired, the racially ostracised and the oppressed communities in India and in Africa and all the marginalised sections across the globe can have their hope in the resurrected Jesus so that they can be elevated to the eternal life experience. The people who are affected by the COVID-19 and Omicron pandemic situations can have their hope in the resurrected Jesus and thus they can aspire for a new normal situation that transcends the post-normal experiences of the contemporary scenario. The text invites the reader towards a new way forward and a new world order to experience the full potential of divine blessings and favours intended for the people of God.

\section{Acknowledgements}

The author would like to acknowledge that the idea of this article was previously presented as an academic presentation 
during the Alumni Refresher Course (26-27 October 2021) of the United Theological College, Bengaluru, India.

\section{Competing interests}

The author declares that he has no financial or personal relationships that may have inappropriately influenced him in writing this article.

\section{Author's contributions}

J.T. is the sole author of this research article.

\section{Ethical considerations}

This article follows all ethical standards for research without direct contact with human or animal subjects.

\section{Funding information}

This research received no specific grant from any funding agency in the public, commercial, or not-for-profit sectors.

\section{Data availability}

Data sharing is not applicable to this article as no new data were created or analysed in this study.

\section{Disclaimer}

The views and opinions expressed in this article are those of the author and do not necessarily reflect the official policy or position of any affiliated agency of the author.

\section{References}

Anderson, P.N., 2008, 'From one dialogue to another: Johannine Polyvalence from origins to receptions', in T. Thatcher \& S.D. Moore (eds.), Anatomies of narrative criticism: The past, present, and futures of the Fourth Gospel as literature, pp. 93-120, SBL Press, Atlanta, GA

Beasley-Murray, G.R., 1999, John, Word Biblical Commentary 36, Thomas Nelson Publishers, Nashville, TN.

Brant, J.-A.A., 2004, Dialogue and drama: Elements of Greek tragedy in the Fourth Gospel, Hendrickson, Peabody, MA.

Brant, J.-A.A., 2011, John, Paideia Commentaries on the New Testament, Baker Academic, Grand Rapids, MI.

Carson, D.A., 1991, The Gospel according to John, The Pillar New Testament Commentary, Apollos, Leicester.

Cole, S.J., 2015, The evidence for Jesus' resurrection (John 20:1-10), viewed 08 December 2021, from https://bible.org/seriespage/lesson-100-evidence-jesusresurrection-john-201-10.

Duke, P., 1985, Irony in the Fourth Gospel, John Knox, Atlanta, GA.
Estes, D., 2008, The temporal mechanics of the Fourth Gospel: A theory of hermeneutical relativity in the Gospel of John, BINS 92, E. J. Brill, Leiden.

Ford, D.F., 2021, The Gospel of John: A theological commentary, Baker Academic Press, Grand Rapids, MI.

Gorman, M.J., 2021, A missional paradigm for the resurrection, viewed 14 October 2021, from http://www.michaeljgorman.net/2011/05/31/a-missional-paradigmfor-the-resurrection/.

Gowler, D.B., 2000, 'Heteroglossic trends in biblical studies: Polyphonic dialogues or clanging cymbals?', Review and Expositor 97(4), 443-466. https://doi. org/10.1177/003463730009700405

Kapoor, R., 2011, 'Is there a postnormal time? From the illusion of normalcy to the design for a new normalcy', Futures 43(2), 216-220. https://doi.org/10.1016/ j.futures.2010.10.012

Kim, S., 2018, The kingship of Jesus in the Gospel of John, Wipf \& Stock Publishers, Eugene, OR.

Köstenberger, A.J., 2004, John, BECNT 4, Baker Academic Press, Grand Rapids, MI.

Lawrence, A.B., 2018, 'Polyvalent approach', in A.B. Lawrence (ed.), Approaches to the New Testament: A handbook for students and pastors, pp. 428-430, SAIACS, Bengaluru.

Lincoln, A.T., 2000, Truth on trial: The lawsuit motif in the Fourth Gospel, Hendrickson, Peabody, MA.

Malina, B.J. \& Rohrbaugh, R.L., 1998, Social-science commentary on the Gospel of John, Fortress Press, Minneapolis, MN.

Maniparampil, J., 2004, Reading the Fourth Gospel: A textbook for students of Gospel according to John, Claretian Publications, Bangalore.

Martyn, J.L., 1979, History and theology in the Fourth Gospel, Abingdon, Nashville, TN.

Moloney, F.J., 1998, The Gospel of John, Sacra Pagina 4, The Liturgical Press, Collegeville, PA.

Moloney, F.J., 2005, The Gospel of John: Text and context, BINS 72, E. J. Brill, Boston, MA.

Mulder, F., 2021, Christ's resurrection as unique missional paradigm-A refreshing dialogue with Rev. Johnson Thomaskutty from India in Holland, viewed 14 October 2021, from https://resurrectionhope.blogspot.com/2011/05/christsresurrection-as-unique.html.

Murray-Miller, G., 2010, 'A narrative of death and resurrection: Emplotment and decadence in nineteenth-century French Catholic ideology', Arc: The Journal of the Faculty of Religious Studies 38(McGill University), 163-175.

Ravetz, J.R. \& Funtowics, S.O. 1999, 'Post-normal, science: An insight now maturing', Futures 31(7), 641-646.

Ravetz, J.R., 1993, 'Science for the post-normal age', Futures 25(7), 735-755. https:// doi.org/10.1016/0016-3287(93)90022-L

Ridderbos, H., 1987, The Gospel of John: A theological commentary, Eerdmans, Grand Rapids, MI.

Sardar, Z. \& Sweeney, J.A., 2016, 'The three tomorrows of postnormal times', Future 75, 1-13. https://doi.org/10.1016/j.futures.2015.10.004

Sardar, Z., 2010, 'Welcome to postnormal times', Futures 42(5), 435-444. https://doi. org/10.1016/j.futures.2009.11.028

Smith, D.M., 1999, John, Abingdon New Testament Commentary, Abingdon Press, Nashville, TN.

Stibbe, M.W.G., 1993, John, Sheffield Academic Press, Sheffield.

Thomaskutty, J., 2015, Dialogue in the book of signs: A polyvalent analysis of John 1:19-12:50, BINS 136, E. J. Brill, Leiden.

Thomaskutty, J., 2018, Saint Thomas the Apostle: New Testament, Apocrypha, and Historical Traditions, T \& T Clark Jewish and Christian Texts Series 25, Bloomsbury T \& T Clark, London.

Thomaskutty, J., 2021, 'Reading John 11:1-45 from a Postnormal Times (PNT) Perspective', Professorial Lecture presented at the United Theological College, Bengaluru, September 30, 2021, pp. 1-17.

Vistar, D.V., 2019, The cross-and-resurrection: The supreme sign in John's Gospel, WUNT 508, Mohr Siebeck, Tübingen.

Witherington, B., 1995, John's wisdom: A commentary on the Fourth Gospel, Westminster John Knox Press, Louisville, KY. 